\title{
Comparative study and assessment of the knowledge, attitude and practice of pharmacovigilance among first, second and third professional medical students of PMCH, Dhanbad
}

\author{
Mona Kumari*, A. K. Choudhary
}

Department of Pharmacology, Patliputra Medical College and Hospital (P.M.C.H.), Dhanbad, Jharkhand, India

\author{
Received: 30 June 2020 \\ Revised: 02 August 2020 \\ Accepted: 03 August 2020 \\ *Correspondence: \\ Dr. Mona Kumari, \\ Email: drmonakumari@gmail.com
}

Copyright: (c) the author(s), publisher and licensee Medip Academy. This is an open-access article distributed under the terms of the Creative Commons Attribution Non-Commercial License, which permits unrestricted non-commercial use, distribution, and reproduction in any medium, provided the original work is properly cited.

\begin{abstract}
Background: Pharmacovigilance awareness among medical students is very important for preventing ADR underreporting. Present study was conducted to know extent of Pharmacovigilance awareness among students and impact of Pharmacovigilance teaching.

Methods: Questionnaire based study about KAP towards ADR and Pharmacovigilance was carried out at Patliputra Medical College, Dhanbad. Of 150 questionnaires distributed to $1^{\text {st }}, 2^{\text {nd }}$ and $3^{\text {rd }}$ Professional students, 106 were returned.

Results: Pharmacovigilance Awareness was $20 \%$ in 1 st, $91 \%$ in $2^{\text {nd }}$ and $94 \%$ in $3^{\text {rd }}$ Professional students. Only $10 \%$ of $1^{\text {st }}, 82 \%$ of $2^{\text {nd }}$ and $88 \%$ of $3^{\text {rd }}$ Professional students knew about Pharmacovigilance and its purpose. Regarding International and National ADR monitoring body, only $7 \%$ of $1^{\text {st }}, 50 \%$ of $2^{\text {nd }}$ and $63 \%$ of $3^{\text {rd }}$ professional students knew. Only $13 \%$ of $1^{\text {st }}, 45 \%$ of $2^{\text {nd }}$ and $56 \%$ of $3^{\text {rd }}$ Professional students knew about local AMC. $40 \%$ of $1^{\text {st }}, 86 \%$ of $2^{\text {nd }}$ and $88 \%$ of $3^{\text {rd }}$ professional students wanted detailed curricular teaching of Pharmacovigilance. $17 \%$ of $1^{\text {st }}$ professional students had seen ADR, none $(0 \%)$ had seen /reported ADR form. Of $2^{\text {nd }}$ and $3^{\text {rd }}$ professional students, $45 \%$ and $75 \%$ had seen ADR but only $34 \%$ and $56 \%$ had seen ADR form and $19 \%$ and $38 \%$ had reported ADR/seen ADR reporting.

Conclusions: $2^{\text {nd }}$ and $3^{\text {rd }}$ professional students had better knowledge and attitude towards pharmacovigilance. As $1^{\text {st }}$ professional students underwent pharmacovigilance teaching, their KAP improved significantly. There existed huge gap between ADR experienced and ADR reporting by all medical students.
\end{abstract}

Keywords: ADR, Attitude, KAP, Knowledge, Medical students, Pharmacovigilance, Practices

\section{INTRODUCTION}

The etymological roots for the word 'pharmacovigilance' are: pharmakon (Greek for drug) and vigilare (Latin for to keep watch). World Health Organization (WHO) defines Pharmacovigilance as "the science and activities relating to the detection, assessment, understanding and prevention of adverse effects or any other possible drugrelated problems". ${ }^{1}$
The greatest of all drug disasters was the thalidomide tragedy which came into focus in December 1961 with the publication of a letter in The Lancet by Dr. William McBride, the Australian obstetrician who first suspected a causal link between serious fetal deformities (phocomelia) and thalidomide use during pregnancy. ${ }^{2}$ It caused the single biggest change to regulation of drugs worldwide. Thalidomide's adverse effects shifted the focus of drug safety worldwide from reactive to proactive. It led to development of regulations mandating 
specific safety surveillance before marketing as well as post-marketing pharmacovigilance. The main objective of $\mathrm{PV}$ is to quantify previously recognized ADRs, to identify unrecognized ADRs, to evaluate the effectiveness of medicines in real-world situations, and to decrease mortality and morbidity associated with ADRs.

In 1968, WHO promoted the 'Programme for International Drug Monitoring (PIDM)’ a pilot project aimed to centralize world data on adverse drug reactions (ADRs). Since 1978, Uppsala Monitoring Centre (UMC) located at Uppsala, Sweden co-ordinates the International Drug Monitoring program (IDM) to which member countries send their reports to be processed, evaluated and entered into an international database called VigiBase. ${ }^{3}$ Vigi base is global Individual Case Safety Report (ICSR) database that contains ICSRs submitted by the participating member states enrolled under WHO's PIDM. It is the single largest drug safety data repository in the world. As of June 2020, 140 countries have joined the WHO PIDM, and in addition, 31 associate members are awaiting full membership.

Indian pharmaceutical industry is world's third largest in terms of volume, worth about US\$ 33 billion (2016). In India, ADRs are among the leading cause of morbidity and mortality. Approximately $8 \%$ of hospital admissions are due to ADRs and $8-19 \%$ of hospitalized patients experience a serious ADR. Central Drugs Standard Control Organization (CDSCO), New Delhi, under the aegis of Ministry of Health and Family Welfare, Government of India initiated a nation-wide Pharmacovigilance Programme of India (PvPI) in July 2010. PvPI is coordinated by the Indian Pharmacopoeia Commission (IPC) as the National Coordination Centre (NCC). To monitor ADRs and reporting the same to NCC PvPI, ADR Monitoring Centres (AMCs) have been set up all over India.

At present more than 250 AMCs (medical colleges, district and corporate hospitals etc.) are enrolled under PvPI across the country. ADR monitoring centres collect reports from healthcare professionals and patients and submit them as individual case safety reports (ICSR) to NCC-PvPI, which works in collaboration with the global ADR monitoring centre- UMC, Sweden to contribute in the global ADRs data base. Currently, India's total contribution to Vigi base is more than 280,000 ICSRs. In 2016 the completeness score for the Indian ICSRs as per the UMC documentation grading was 0.82 out of $1 .{ }^{4}$ To extend the outreach of PvPI, toll-free helpline (1800 180 3024) with SMS feedback facility, an android mobile application for reporting ADRs (since 2015) by PvPI and ADR reporting form (in Hindi and 9 other regional languages) were made available. PvPI also uses social media including LinkedIn (NCC PvPI), WhatsApp (7042343309), Facebook (Ncc-PvPI Ipc) and Twitter (@IPCNCCPvPI). ${ }^{5-7}$

Backbone of pharmacovigilance program is spontaneous reporting of ADR by health care professionals but under reporting of ADR is widely prevalent and is the cause of serious concern. Earlier Studies show that only 6-10\% of all ADR cases are reported. Medical students could play a major role and bring a paradigm shift in successful implementation of pharmacovigilance program if adequate knowledge and skill are imparted to them during undergraduate training career. At present they don't have any significant role which is largely due to inadequate training and exposure regarding ADR reporting. Very few studies are there to assess the knowledge, attitude, and practice (KAP) of pharmacovigilance among undergraduate medical students. This study was conducted for the assessment of KAP regarding pharmacovigilance/ ADR reporting and to compare the result among different groups in medical students in Dhanbad, Jharkhand to gain the perspective of how much impact the undergraduate pharmacovigilance education is making on them, the future prescribers.

\section{METHODS}

This study was conducted at Patliputra Medical College and Hospital (PMCH) a tertiary care Hospital in Dhanbad, Jharkhand, India. The approval for conducting this study was obtained from the Institutional Ethics Committee of PMCH, Dhanbad. The duration of the study was 4 months, from February 2020 to May 2020. The study was a cross-sectional questionnaire-based study. The study participants consisted of $1^{\text {st }}, 2^{\text {nd }}$ and $3^{\text {rd }}$ professional medical students who gave their informed consent.

The questionnaire was developed by the author to judge the basics of pharmacovigilance and had three sections, i.e., knowledge, attitude and practice toward pharmacovigilance and ADR reporting. Pretesting of questionnaire was done on 10 randomly selected medical students of the institute. The questionnaire was finalized after ambiguous and unsuitable questions were removed or modified based on the result of pre-test. Finally, questionnaire consisted of 14 questions- knowledge (first 8 questions), attitude (3 questions), and practice (3 questions) toward pharmacovigilance and ADR reporting.

150 questionnaires were distributed to $1^{\text {st }}, 2^{\text {nd }}$ and $3^{\text {rd }}$ professional medical students and were asked to return the duly filled questionnaires the same day.

\section{Data analysis}

The data were collected and analyzed and results were depicted in the form of percentages. All the questions (except 2, 3, 4 and 5) were having only 2 options- in the form of yes/no. Questions 2, 3, 4 and 5 were evaluated as correct or wrong response/explanation. Therefore, every response in each question was evaluated as 0 or 1 and thus analysed using MS Excel. 


\section{RESULTS}

A total of 106 students responded out of 150 distributed questionnaires. Out of 50 students, $301^{\text {st }}$ professional students $(60 \%)$ responded. In case of $2^{\text {nd }}$ and $3^{\text {rd }}$ professional students it was 44 out of $50(88 \%)$ and 32 out of $50(64 \%)$ respectively.

Table 1: Response to knowledge, attitude and practice related questions.

\begin{tabular}{|c|c|c|c|}
\hline Questions & $\begin{array}{l}1^{\text {st }} \text { prof. } \\
\text { response } \\
(\%)\end{array}$ & $\begin{array}{l}2^{\text {nd }} \text { prof. } \\
\text { response } \\
(\%)\end{array}$ & $\begin{array}{l}3^{\text {rd }} \text { prof. } \\
\text { response (\%) }\end{array}$ \\
\hline \multicolumn{4}{|l|}{ Knowledge related questions } \\
\hline Have you heard of pharmacovigilance? & $6 / 30(20)$ & 40/44 (91) & 30/32 (94) \\
\hline What is pharmacovigilance? & $3 / 30(10)$ & $36 / 44(82)$ & 28/32 (88) \\
\hline What is the purpose of pharmacovigilance? & $3 / 30(10)$ & $36 / 44(82)$ & $28 / 32(88)$ \\
\hline What is ADR? & $4 / 30(13)$ & $42 / 44(95)$ & $32 / 32(100)$ \\
\hline Who are eligible to report ADRs? & $4 / 30(13)$ & $30 / 44(68)$ & 25/32 (78) \\
\hline Where is International ADR monitoring centre located? & $2 / 30(7)$ & $22 / 44(50)$ & 20/32 (63) \\
\hline What is the National regulatory body for monitoring ADRs in India? & $2 / 30(7)$ & $20 / 44(45)$ & $20 / 32(63)$ \\
\hline $\begin{array}{l}\text { Is there any pharmacovigilance centre or ADR monitoring centre in } \\
\text { Dhanbad? }\end{array}$ & $4 / 30(13)$ & $20 / 44(45)$ & $18 / 32(56)$ \\
\hline \multicolumn{4}{|l|}{ Attitude related questions } \\
\hline Is Pharmacovigilance essential? & $12 / 30(40)$ & 40/44 (91) & 29/32 (91) \\
\hline Is it important to report ADR? & $10 / 30(33)$ & $40 / 44(91)$ & $30 / 32(94)$ \\
\hline $\begin{array}{l}\text { Should Pharmacovigilance and ADR reporting be taught in detail in the } \\
\text { curriculum? }\end{array}$ & $12 / 30(40)$ & $38 / 44(86)$ & $28 / 32(88)$ \\
\hline \multicolumn{4}{|l|}{ Practice related questions } \\
\hline Have you ever come across an ADR form? & $0 / 30(0)$ & $15 / 44(34)$ & $18 / 32(56)$ \\
\hline $\begin{array}{l}\text { Have you ever come across an ADR in any patient during the ward duty } \\
\text { in the hospital or elsewhere? }\end{array}$ & $5 / 30(17)$ & 20/44 (45) & $24 / 32(75)$ \\
\hline Have you reported any ADR or seen ADR being reported? & $0 / 30(0)$ & $8 / 44(19)$ & $8 / 32(25)$ \\
\hline
\end{tabular}

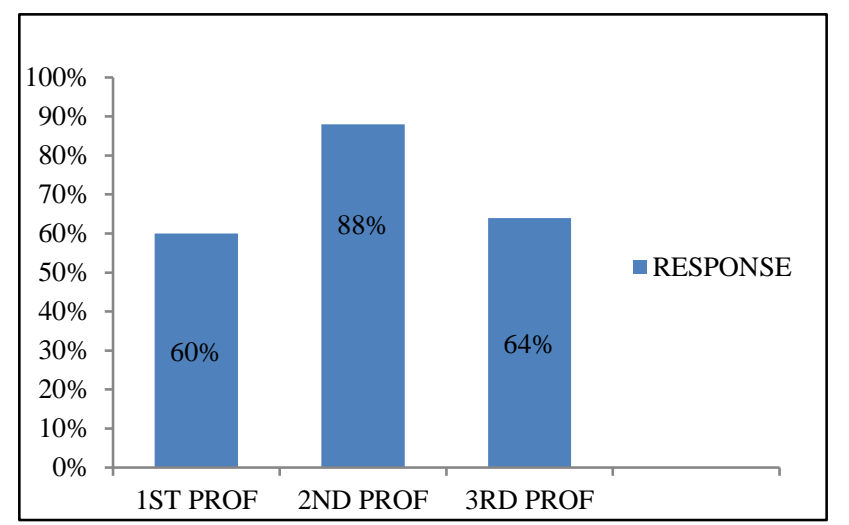

Figure 1: Response.

\section{Response to knowledge related questions}

Nearly $20 \%$ of $1^{\text {st }}$ professional students, $91 \%$ of $2^{\text {nd }}$ professional students and $94 \%$ of $3^{\text {rd }}$ professional students had heard of pharmacovigilance. $1^{\text {st }}$ Professional (10\%) students showed lack of knowledge and awareness of the purpose of pharmacovigilance but $2^{\text {nd }}(82 \%)$ and $3^{\text {rd }}$ professional (88\%) had fairly good response. Few students of $1^{\text {st }}$ professional (13\%) knew about ADR but awareness of ADR among $2^{\text {nd }}(95 \%)$ and $3^{\text {rd }}$ professional $(100 \%)$ students were very good.

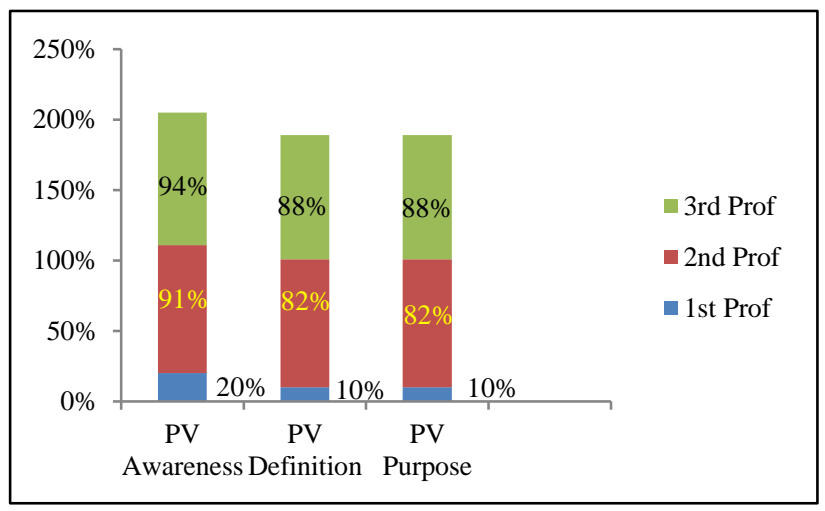

Figure 2: Response of students in relative percentages about PV awareness, PV definition and purpose (knowledge related questions- I).

Regarding eligibility criteria for reporting ADR, $1^{\text {st }}$ professional students were not much aware $(13 \%)$ but $2^{\text {nd }}$ $(68 \%)$ and $3^{\text {rd }}$ professional $(78 \%)$ were above average. Very few $1^{\text {st }}$ professional (7\%) students had knowledge 
about international ADR monitoring centre-Uppsala, Sweden whereas $2^{\text {nd }}(50 \%)$ and 3 rd $(63 \%)$ professional students knew about it. Similarly, very few $(7 \%)$ of $1^{\text {st }}$ professional students had knowledge about national ADR monitoring body-CDSCO in comparison to $2^{\text {nd }}(45 \%)$ and $3^{\text {rd }}(63 \%)$ Professional students. About the knowledge of AMC centre at PMCH, Dhanbad, it was least among $1^{\text {st }}$ professional $(13 \%)$ and near average in $2^{\text {nd }}$ professional $(45 \%)$ and $3^{\text {rd }}$ professional $(56 \%)$ students.

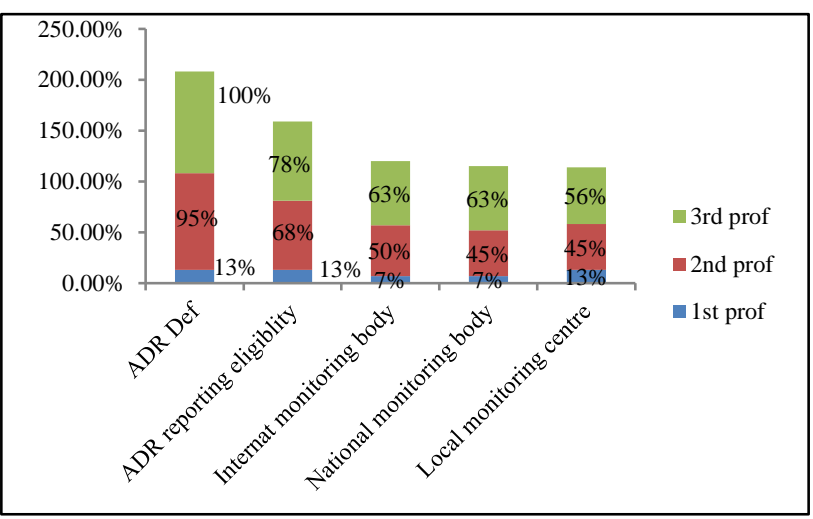

Figure 3: Response of students in relative percentages about ADR Definition, ADR eligibility, international, national and local ADR monitoring body (knowledge related questions- II).

\section{Response to attitude related questions}

To evaluate the attitude of students towards pharmacovigilance, they were given 3 questions. The attitude of $1^{\text {st }}$ professional students about importance of pharmacovigilance was about $40 \%$ in comparison to $2^{\text {nd }}$ $(91 \%)$ and $3^{\text {rd }}$ professional $(91 \%)$. Regarding importance of ADR reporting, $2^{\text {nd }}(91 \%)$ and $3^{\text {rd }}(94 \%)$ had much better attitude towards it than $1^{\text {st }}$ professional students (33\%). In response to the question of giving more importance of pharmacovigilance in the curriculum, even the $1^{\text {st }}$ professional students scored near average $(40 \%)$ but certainly $2^{\text {nd }}(86 \%)$ and $3^{\text {rd }}(88 \%)$ professional students showed better attitude.

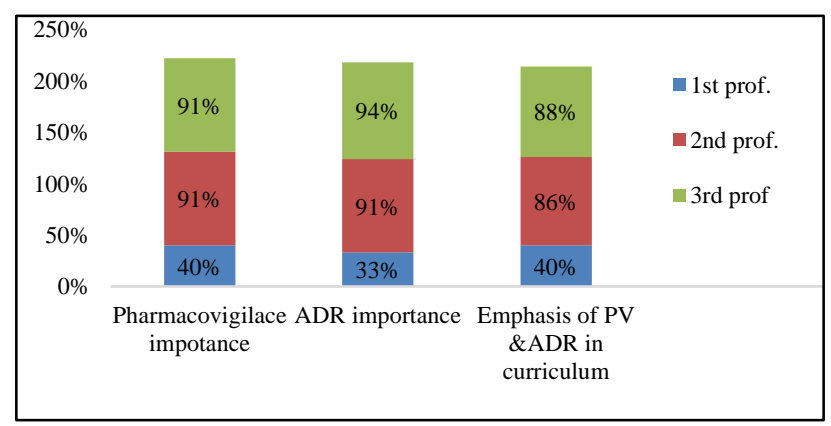

Figure 4: Response of students in relative percentages about importance of pharmacovigilance, ADR and emphasis on PV/ADR in curriculum (attitude related questions).

\section{Response to practice related questions}

There were 3 questions to evaluate the response to practice. In response to whether they had ever seen an ADR form the $3^{\text {rd }}$ professional $(56 \%)$ had much better practice than $2^{\text {nd }}(34 \%)$ and $1^{\text {st }}(0 \%)$ professional students. $75 \%$ of $3^{\text {rd }}$ professional students had come across an ADR in hospital/clinics in comparison to only $45 \%$ in case of $2^{\text {nd }}$ professional and $17 \%$ in case of $1^{\text {st }}$ professional students but only $25 \%$ of $3^{\text {rd }}$ professional and $19 \%$ of $2^{\text {nd }}$ professional students had ever reported ADR or seen ADR being reported in comparison to $1^{\text {st }}$ professional students who had never reported an ADR or seen any ADR being reported $(0 \%)$.

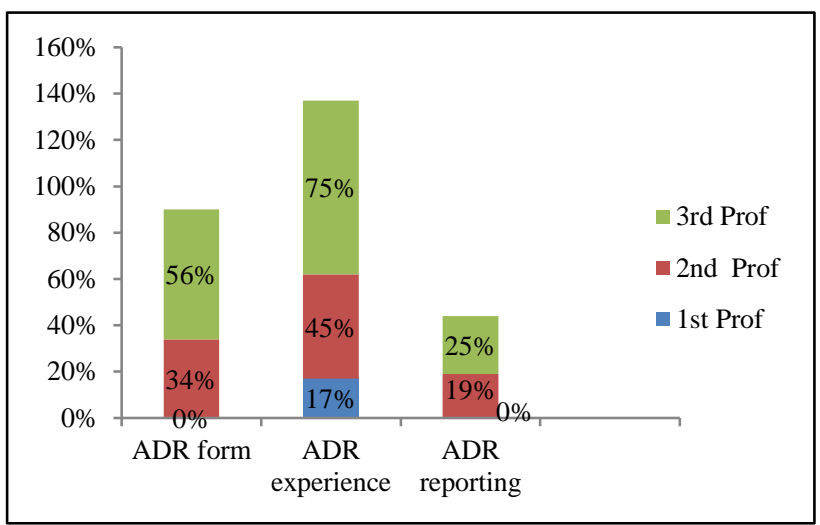

Figure 5: Response of students in relative percentages about ADR forms, ADR experience and ADR reporting (practice related questions).

\section{DISCUSSION}

This study was conducted with an aim of not only evaluating the knowledge, attitude and practice (KAP) among medical students but also to compare it between them to show the effect of teaching about pharmacovigilance and ADR in the curriculum. It was also done to emphasize the importance of pharmacovigilance and ADR reporting in daily practice to the budding doctors.

As the results of the study unfolded, we found out that the knowledge and awareness of pharmacovigilance and ADR in $1^{\text {st }}$ professional students $(10 \%$ and $13 \%)$ was much less in comparison to $2^{\text {nd }}$ and $3^{\text {rd }}$ professional students. This well correlated with the findings for $1^{\text {st }}$ professional students as found by Meher et al study in Puducherry. ${ }^{8}$ This reflected the awareness and knowledge in public and educated persons in general about pharmacovigilance and ADR. Inacio et al study"the value of patient reporting to the pharmacovigilance system: a systematic review" concluded that patient reporting adds new information and perspective about ADRs in a way otherwise unavailable. ${ }^{9}$ This can contribute to better decision-making processes in regulatory activities. Therefore, we should also 
emphasize on increasing the general public awareness about pharmacovigilance.

Similarly $1^{\text {st }}$ professional students had less knowledge regarding pharmacovigilance definition (10\%), its purpose (10\%), ADR eligibility criteria (13\%), international ADR monitoring centre, Uppsala, Sweden (7\%) National ADR monitoring body CDSCO (7\%) or awareness regarding presence of pharmacovigilance centre in PMCH, Dhanbad (13\%) but they had a relatively better attitude regarding importance of pharmacovigilance $(40 \%)$, importance of reporting ADR $(33 \%)$ and detailed teaching of pharmacovigilance and ADR reporting in curriculum (40\%) showing their receptive mindset ready to learn things. Regarding practise, they fared poorly- be it awareness of ADR form $(0 \%)$ or ADR in patients $(17 \%)$ or reporting of ADR (3\%). It showed their very little exposure to patients and clinical care in hospital, wards or clinics.

$2^{\text {nd }}$ and $3^{\text {rd }}$ Professional students fared well above average in relation to a) awareness of pharmacovigilance (91\% and 94\%), b) definition of pharmacovigilance and its purpose (82\% and $88 \%$ ) c) definition of ADR (95\% and $100 \%)$. This well correlated with the findings for $3{ }^{\text {rd }}$ professional students as found by Parthiban et al (81\%) study in Puducherry and Gaude et al study in Goa (70\% and $82 \%$ ) and Meher et al study $(61 \%$ and $50 \%)$ but is way ahead in comparison to study by Vakade et al (34\%) in 2016 in Ahmednagar and Chhabra et al study $(36 \%)$ on dental students in Jodhpur. ${ }^{8,10,11-13}$ Probably this difference can be attributed to introduction of pharmacovigilance in curriculum only 3-4 year back. These contrast findings in comparison to $1^{\text {st }}$ year reflected the fact that $2^{\text {nd }}$ and $3^{\text {rd }}$ professional students had pharmacology teaching programme involving pharmacovigilance and ADR in addition to wider exposure to numerous patients in clinical postings in wards/clinics/hospital leading to expansion of their clinical knowledge about drugs, their side effects and their importance in patient care. This was well illustrated in the study done by Ganesan et al from JIPMER, Puducherry. ${ }^{14}$

However, $2^{\text {nd }}$ and $3^{\text {rd }}$ professional students' response was near or above average regarding eligibility to report ADR (68\% and 78\%), international ADR monitoring body- Uppsala, Sweden (50\% and 63\%), national ADR monitoring Body-CDSCO (45\% and 63\%) and awareness of pharmacovigilance centre in $\mathrm{PMCH}$, Dhanbad (45\% and 56\%).

$2^{\text {nd }}$ and $3^{\text {rd }}$ professional students showed strong positive attitude towards a) importance of pharmacovigilance (91\% each), b) importance of reporting ADR (91\% and 94\%) and c) detailed teaching of pharmacovigilance and ADR reporting in curriculum ( $86 \%$ and $88 \%$ ). This result correlated well with the Meher et al study in Puducherry (95\% and $85 \%$ ) and Gaude et al study in Goa (93\% and 82\%) and Vakade et al study in
Ahmednagar (88.63\% and $85.22 \%$ ) and Parthiban et al study in Puducherry (90.3\% and $84 \%$ ) and Upadhyaya et al study (ADR importance-94\%) in Vadodara, Gujarat. . $^{8,10,112,14}$ This not only reflected their strong young receptive mind but also their willingness to learn more about ADR with their increased exposure to patient care which showed greater importance of drugs and their side effects than they had perceived earlier in life.

Regarding practices, results showed the poor implementation of pharmacovigilance and ADR forms in day to day practice. Only $34 \%$ of $2^{\text {nd }}$ and $56 \%$ of $3^{\text {rd }}$ professional students had ever come across ADR forms. Although $45 \%$ and $75 \%$ of $2^{\text {nd }}$ and $3^{\text {rd }}$ professional students respectively had seen an ADR (adverse drug reaction) but only $19 \%$ of $2^{\text {nd }}$ and $25 \%$ of $3^{\text {rd }}$ professional students had ever reported an ADR or seen an ADR being reported. This well correlated with the findings in the Meher et al study in Puducherry [where $53 \%$ of $2^{\text {nd }}\left(2^{\text {nd }}\right.$ year) and $60 \%$ of $3^{\text {rd }}$ (prefinal year) had come across ADR form but only $5 \%$ of $2^{\text {nd }}$ and $10 \%$ of $3^{\text {rd }}$ had reported an ADR] and Gaude et al study in Goa [where $38.9 \%$ of Final year students had seen ADR, but only $6.3 \%$ reported the ADR and only $14.7 \%$ of students were aware of ADR form] and Vakade et al study in Ahmednagar where 34.09\% interns were aware of ADR reporting form and 50\% interns had experienced ADR but only $2.27 \%$ interns had reported to pharmacovigilance centre. $8,11,12$

A better training about pharmacovigilance in undergraduate curriculum might help to solve this emergent problem of underreporting of ADR's. This was well highlighted in Reumerman et al review which concluded that there is an urgent need to improve and innovate current pharmacovigilance education for undergraduate healthcare students. ${ }^{16}$ By offering real life pharmacovigilance training, students will increase their knowledge and awareness but can also assist current healthcare professionals to meet their pharmacovigilance obligations. A regular simulated environment and workshop on pharmacovigilance should be conducted for the students and periodic evaluation of their responses should be done. Schutte et al verified this in their study "Learning by doing in the student-run pharmacovigilance program". ${ }^{17}$

One of the limitations of our study was small sample size. It is recommended that similar kind of studies are conducted in other medical colleges.

\section{CONCLUSION}

The results of our study indicate that the acceptable number of medical students specially $2^{\text {nd }}$ and $3^{\text {rd }}$ professional students had a good knowledge and attitude towards pharmacovigilance. As $1^{\text {st }}$ professional students went through pharmacology teaching involving pharmacovigilance and ADR in second year, their 
knowledge, attitude and practice (KAP) improved significantly. There was a huge gap between the ADR experienced, and ADR reported by the medical students. So, there is need of conductance of CMEs, workshops and seminars and hands-on real-life pharmacovigilance training for all medical students, the future prescribers so that whole community can be benefitted.

\section{ACKNOWLEDGEMENTS}

We wish to thank all the $1^{\text {st }}, 2^{\text {nd }}$ and $3^{\text {rd }}$ professional students who have participated in this study and also management of our tertiary care hospital for their constant support and encouragement.

Funding: No funding sources

Conflict of interest: None declared

Ethical approval: The study was approved by the Institutional Ethics Committee

\section{REFERENCES}

1. The safety of medicines in public health programmes: pharmacovigilance an essential tool- World Health Organization. 2006. Available at: https://www.who.int/medicines/areas/qualitysafety/ safetyefficacy/Pharmacovigilance B.pdf

2. McBride WG. Thalidomide and congenital abnormalities. Lancet. 1961;2(1358):90927-8.

3. Making medicines safer- Published by Uppsala Monitoring Centre. Available at: https://view.publitas.com/uppsala-monitoringcentre/making-medicines-safer.

4. Mahajan MM, Thatte UM, Gogtay NJ, Deshpande S. An analysis of completeness and quality of adverse drug reaction reports at an adverse drug reaction monitoring centre in Western India. Perspect Clin Res. 2018;9:123-6.

5. Gupta M, Kharb P, Kalaiselvan V, Shridhar M, Singh GN, Kshirsagar N, et al. World Health Organization. Safety of medicines: pharmacovigilance programme of India. WHO Drug Information. 2018;32(1):10-7.

6. Nimesh S, Chaudhary A, Sharma A, Negi KD. Pharmacovigilance Programme of India: A Review. Acta Scient Pharm Sci. 2019;3(9):12-7.

7. Pharmacovigilance Programme of India (PvPI). Performance Report 2015-16. Available at: http://www.ipc.gov.in/PvPI/pub/Pharmacovigilance\% 20Programme\%20of\%20India\%20Annual\%20perfor mance\%20Report\%202015-2016.pdf.

8. Meher BR, Joshua N, Asha B, Mukherji D. Awareness of pharmacovigilance among undergraduate medical students. Perspect Clin Res. 2015;6(4):217-21.
9. Inácio $\mathrm{P}$, Cavaco $\mathrm{A}$, Airaksinen $\mathrm{M}$. The value of patient reporting to the pharmacovigilance system: a systematic Review: $\mathrm{Br} \mathrm{J}$ Clin Pharmacol. 2017;83(2):227-46.

10. Parthiban G, Nileshraj G, Mangaiarkkarasi A, Ali MR. A survey on knowledge, attitude and awareness of pharmacovigilance among medical students in a teaching hospital, Puducherry. Indian J Basic Appl Med Res. 2015;5(1):198-203.

11. Gaude OS, Sa SD. Assessment of knowledge, attitude, and practices of pharmacovigilance and adverse drug reaction reporting among final year medical students- a questionnaire-based study in a tertiary care hospital in Goa. Nat J Physiol Pharm Pharmacol. 2018;8(12):1657-61.

12. Vakade KP, Sangisetti VM, Binayke MV, Abhavathi VN, Nayak BB. An evaluation of knowledge, attitude and practice of pharmacovigilance among interns in a tertiary care teaching hospital of North Maharashtra. Int J Basic Clin Pharmacol. 2016;5(6):2321-5.

13. Chhabra KG, Sharma A, Chhabra C, Reddy JJ, Deolia SG, Mittal Y. Knowledge, attitude, and practices regarding pharmacovigilance and adverse drug reaction reporting among dental students in a teaching hospital, Jodhpur, India: a cross-sectional study. J Contemp Dent Pract. 2017;18(10):964-9.

14. Ganesan S, Sandhiya S, Reddy KC, Subrahmanyam DK, Adithan C. The impact of the educational intervention on knowledge, attitude, and practice of pharmacovigilance toward adverse drug reactions reporting among health-care professionals in a Tertiary Care Hospital in South India. J Nat Sc Biol Med. 2017;8:203-9.

15. Upadhyaya HB, Vora MB, Nagar JG, Patel PB. Knowledge, attitude and practices toward pharmacovigilance and adverse drug reactions in postgraduate students of tertiary care hospital in Gujarat. J Adv Pharm Technol Res. 2015;6:29-34.

16. Reumerman M, Tichelaar J, Piersma B, Richir MC, van Agtmael MA. Urgent need to modernize pharmacovigilance education in healthcare curricula: review of the literature. Eur J Clin Pharmacol. 2018;74:1235-48.

17. Schutte T, Tichelaar J, Reumerman MO, van Puijenbroek EP, Richir MC, van Agtmael MA. Learning by doing in the student-run pharmacovigilance programme. Clin Therap. 2017;39(8):e2.

Cite this article as: Kumari M, Choudhary AK. Comparative study and assessment of the knowledge, attitude and practice of pharmacovigilance among first, second and third professional medical students of PMCH, Dhanbad. Int J Basic Clin Pharmacol 2020;9:1386-91. 